\section{'Galarina' Apple}

Shahrokh Khanizadeh ${ }^{1}$

Agriculture and Agri-Food Canada, Horticultural Research and Development Centre, 430 Gouin Blvd., St-Jean-sur-Richelieu, QC, Canada, J3B 3E6

François Laurens and Yves Lespinasse

INRA-C.R. d'Angers, Unité d'Amélioration des Espèces Fruitières et Ornementales, 42 Rue Georges Morel, B.P. 57-49071 Beaucouzé Cedex, France

\section{Yvon Groleau, Johanne Cousineau, and Odile Carisse \\ Agriculture and Agri-Food Canada, Horticultural Research and Development Centre, 430 Gouin Blvd., St-Jean-sur-Richelieu, QC, Canada, J3B 3E6}

\section{Jennifer DeEll ${ }^{2}$}

Ontario Ministry of Agriculture, Food and Rural Affairs, 4890 Victoria Ave. $N$, Box 8000, Vineland Station, ON, Canada, LOR 2EO

Additional index words. Malus $\times$ domestica, apple scab resistance, fruit breeding, winter hardy, 'Gala', long shelf life

'Galarina' is a 'Gala' type apple (Malus $\times$ domestica Borkh.). It is very attractive, has a pleasant taste and an excellent shelf-life. The tree is hardy to $-25^{\circ} \mathrm{C}$, and the fruit and leaves are resistant to the common races of apple scab (Venturia inaequalis (Cke) Wint.) due to the presence of the $\mathrm{V}_{f}$ gene derived from Malus floribunda 821 .

\section{Origin}

'Galarina', tested as X4982, originated from a cross made in 1978 between 'Gala' and 'Florina Querina'(Lespinasse et al., 1985), at the Unité d'Amélioration des Espèces Fruitières et Ornementales [Fruit and Ornamental Plant Breeding Unit (FOPBU)] of the Institut National de la Recherche Agronomique (INRA) located in Angers, France (Fig. 1). X4982 was selected and tested at INRA. It was sent in 1990 to Quebec for further evaluation and is now being released by the Quebec apple breeding program (QAPB) located at the Agriculture and Agri-Food Canada (AAFC) Research Centre in St-Jean-sur-Richelieu (Quebec). 'Galarina' was one of a group of genotypes sent by INRA for testing in Quebec and was evaluated by the QABP at a substation located in Frelighsburg (Quebec) for 10 years. Compared to 'Gala', this new cultivar is hardier, retains its fresh eating quality longer in storage, and is resistant to the common races of apple scab, reducing the need for fungicide applications.

Received for publication: 18 Dec. 2001. Accepted for publication 4 June 2002. Agriculture and AgriFood Canada, St-Jean-sur-Richelieu, Contribution No. 335/2002.12.02R

${ }^{1}$ To whom reprint requests should be addressed. E-mail address: KhanizadehS@agr.gc.ca, www. pgris.com

${ }^{2}$ Current address: Fresh Market Quality Program Lead, Ontario Ministry of Agriculture and Food, 1283 Blueline Rd. \& Hwy \#3. Box 587, Simcoe, Ontario, Canada, N3Y 4N5

\section{Description}

'Galarina' trees are moderately vigorous when grafted on the rootstock M.26, with an upright-spreading shape. Fruits are borne on spurs and shoots, which are generally 1 to 3 years of age, and the fruiting zone tends to move rapidly away from the trunk to the outside of the tree (type III bearing habit according to Lespinasse, 1977). 'Galarina' trees are hardy at Frelighsburg, Quebec (lat. $45^{\circ} \mathrm{N}$; long. $\left.72^{\circ} \mathrm{W}\right)$, which has an average winter minimum temperature of $-25^{\circ} \mathrm{C}$. There have been no signs of powdery mildew [Podosphaera leucotricha (Ell. \& Ev.) Salm.] or fireblight [Erwinia amylovora (Burr.) Winslow et al.] infections during the evaluation period. The leaves are small to medium-small in size, ovate to lanceolate, and the margins are mainly serrate, although they can be doubly serrate. The abaxial surface is hairy, the apex is acuminate, and the base is obtuse. The average leaf length to width ratio is 1.0 and the petioles are hairy, 2.5 to $3.8 \mathrm{~cm}$ long, with short stipules when
Fig. 1. Pedigree of 'Galarina' apple. young. The surface of the leaves is medium green and weakly glossy.

Flowering starts at the same time as 'McIntosh' and 1 or $2 \mathrm{~d}$ before 'Gala' in Frelighsburg. Flower buds are dark pink [60A; Royal Horticultural Society Colour Chart (RHS), 1995] in full balloon stage and the flowers are single. When fully open, the ovate petals are slightly overlapping and are white with a mottling of dark pink (RHS 60C) on both sides. The pedicels are green.

'Galarina' fruit mature at the end of September to early October in Frelighsburg, $\approx 1$ to 2 weeks after 'McIntosh', at the same time as 'Cortland' and usually $\approx 1$ to $2 \mathrm{~d}$ after 'Gala'. Fruits are small to medium size (axial diameter 46 to $61 \mathrm{~mm}$, transverse diameter 51 to $65 \mathrm{~mm}$ ) (Fig. 2). Fruit weights range from 75 to $134 \mathrm{~g}$ with an overall average of $106 \mathrm{~g}$ at harvest. Fruit shape is mainly round-conic and the average length to width ratio is 0.9 (Fig. 2). The outline of the fruit is irregular; there is ribbing along the body, and the distal end is five-pointed. The skin is smooth, thick and tough. The skin color is variable: $65 \%$ to $100 \%$ blushed to washed orange-red (RHS 179A) to dark red (RHS 185A) fading on the shaded side, with dark red (RHS 185A to 187B) stripes, over a greenish-yellow ground (RHS $2 \mathrm{C}$ ). There is russeting in the cavity that can sometimes radiate out $\approx 1$ to $2 \mathrm{~mm}$. Lenticels are conspicuous, medium in size, and increase in numbers at the distal end. Surface bloom is scant. The stem is medium to long (1.5 to 2.0 $\mathrm{cm})$, small to medium in diameter, and is green although it can be red when exposed to sun. The cavity is acuminate to acute, fairly deep to deep with a narrow to medium width. The basin is prominently ribbed, medium depth to deep with a narrow to medium width. The large calyx is persistent with erect lobes, open, and the calyx tube is funnel-shaped; the stamens are in median position. The medium-size core is mainly closed to partially open, located in median position with clasping core lines that are not prominent. The carpels are round and may be cracked but not tufted. The distal end of the carpels is emarginate and the cells are symmetrical and slightly abaxile. The seeds are large, not tufted, can be flattened on one side

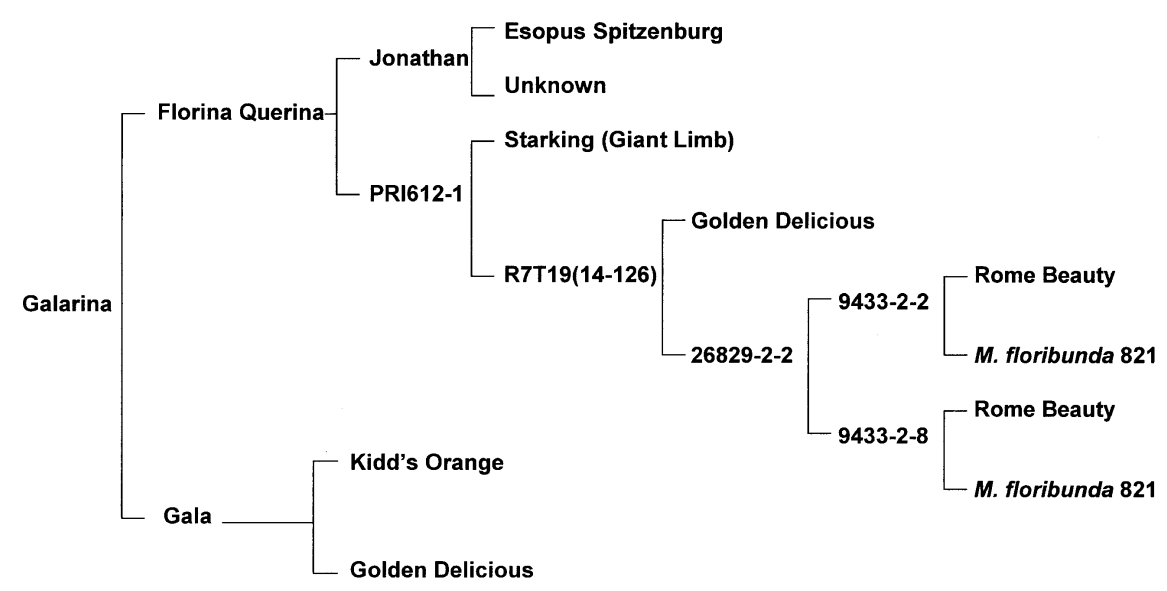




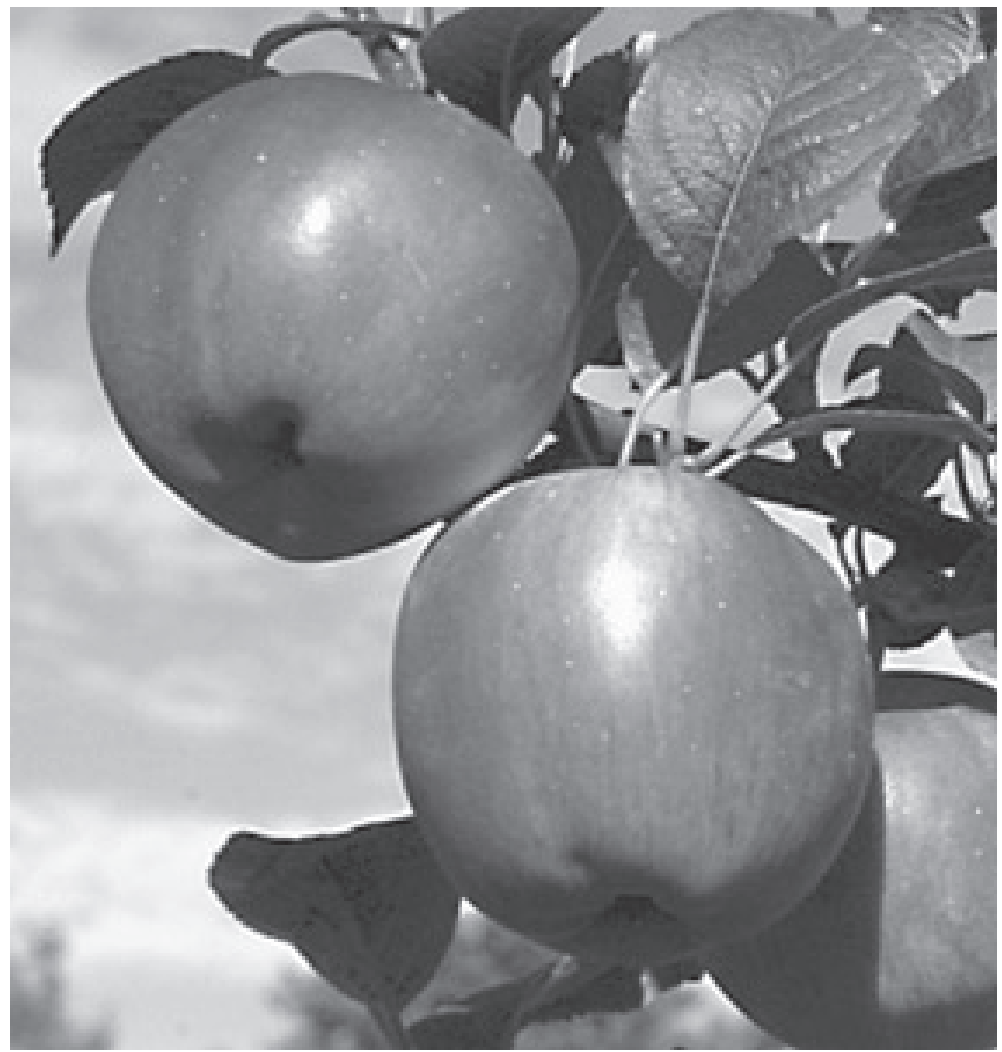

average ( $12 \%$ and $0.6 \%$, respectively).

'Galarina' was planted in several locations and compared to other known cultivars at growers field and also at Frelighsburg (Quebec) using M26 as rootstocks and trained as vertical axis. Five trees of each cultivar were planted $2 \mathrm{~m}$ apart with 4-m spacing between the rows in 1995. Redfree had significantly higher cumulative yield than 'Querina Florina'. No significant differences were observed between the other cultivars. Cumulative yields (1998 to 2000) were $43.0 \pm 2.6 \mathrm{~kg} /$ tree for 'Galarina' compared with 'Redfree' (50.0 \pm 6.7/tree), 'Querina Florina' ( $38 \pm 1.4 \mathrm{~kg} /$ tree), 'NovaSpy' $(46 \pm 1.8 \mathrm{~kg} /$ tree $)$, and 'McIntosh' $(48 \pm 3.5 \mathrm{~kg} /$ tree $)$

\section{Availability}

A trademark is pending for 'Galarina'. Limited quantities of nonindexed budwood are available for research purposes (universities and research stations) from Shahrokh Khanizadeh (North America) or from François Laurens (Europe) with a written request. Trees and/or budwood may be obtained from Brandt's Fruit Trees in the United States and Canada. Nurseries may inquire about "nonexclusive sub-licenses" directly to Brandt's Fruit Trees.

\section{Literature Cited}

Fig. 2. Fruits of 'Galarina' apple.

and the tip is obtuse. At harvest the flesh is crisp, juicy, and very firm $(9.5 \mathrm{~kg}$ as measured by a EPT-1 pressure tester made by Lake City Technical Products, Kelowna, B.C. Canada). The yellowish-white flesh (RHS 11D) can be tinged with red near the skin and does not brown after cutting. The flavor is good, aromatic, and slightly tart. The acidity is average $(0.69 \%$ malic acid $)$ and the soluble solids are low $(11.1 \%)$. After 4.5 months in air at 2 to $4{ }^{\circ} \mathrm{C}$, the fruit is still very firm $(8.7 \mathrm{~kg})$ and its fresh eating qualities are excellent. Juice produced from the fruit after storage is very clear, orange-salmon in color (RHS 32C), with average acidity $(0.57 \%)$ and soluble solids $(12.2 \%)$. After 6 months in CA $(2.5 \%$ $\left.\mathrm{O}_{2}, 4.5 \% \mathrm{CO}_{2}\right)$, the fruit is very firm $(8.3 \mathrm{~kg})$ and the soluble solids and acidity are both

Lespinasse, J.M. 1977. Types de fructification et incidence sur la conduite de l'arbre. In: La conduite du pommier. Institut national de vulgarisation pour les fruits, légumes et champignons (INVUFLEC). Institut National de la Recherche Agronomique (INRA), Paris.

Lespinasse, Y., J.M. Olivier, J.M. Lespinasse, and M. Le Lézec. 1985. Florina Quérina la résistance du pommier à la tavelure. Arbor. Fruit. 32(378):43-47.

Royal Horticultural Society Colour Chart. 1995. Royal Hort. Soc., London, U.K. 